PAPER • OPEN ACCESS

\section{Effect of Dairy and Non-Dairy Ingredients on the Physical Characteristic of Ice Cream: Review}

To cite this article: Andreas Romulo et al 2021 IOP Conf. Ser.: Earth Environ. Sci. 794012145

View the article online for updates and enhancements.
You may also like

\begin{tabular}{l} 
- Development of a Full Ice-cream Cone \\
\hline Model for Halo Coronal Mass Ejections \\
Hyeonock Na, Y.-J. Moon and Harim Lee \\
- The Significance of the Influence of the \\
CME Deflection in Interplanetary Space on \\
the CME Arrival at Earth \\
Bin Zhuang, Yuming Wang, Chenglong \\
Shen et al. \\
- Ice cream and orbifold Riemann-Roch \\
A. Buckley, M. Reid and S. Zhou
\end{tabular}

The Electrochemical Society

243rd Meeting with SOFC-XVIII

Boston, MA • May 28 - June 2, 2023

Accelerate scientific discovery!
Learn More \& Register

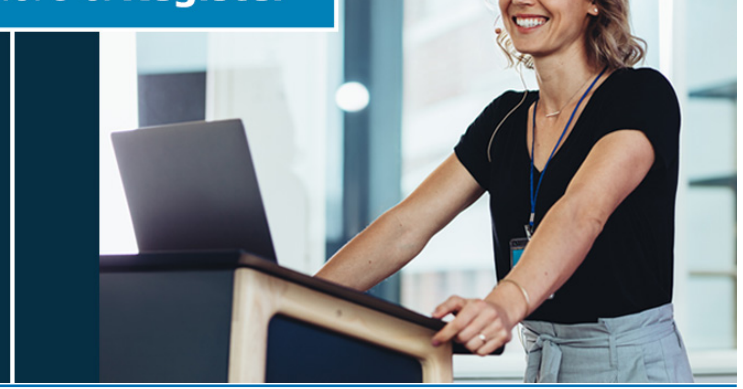

This content was downloaded from IP address 52.87.193.239 on 26/04/2023 at 09:46 


\title{
Effect of Dairy and Non-Dairy Ingredients on the Physical Characteristic of Ice Cream: Review
}

\author{
Andreas Romulo, Bayu Meindrawan, Marpietylie \\ Food Technology Department, Faculty of Engineering, Bina Nusantara University, \\ Jakarta, Indonesia, 11480 \\ Email: andreas.romulo@binus.edu
}

\begin{abstract}
Ice cream is a type of sweetened frozen food, which use cow's milk and sugar as main ingredients. Due to its high sugar and fat content, the excessive consumption of ice cream could contribute to the significant health impact, especially for those who suffer diabetes. Moreover, some people could not consume the ice cream because of its inability to digest the lactose content in cow's milk in their body. In recent years, there is some great innovation to replace cow's milk as the main ingredients of ice cream with other milk substitutes. In order to obtain the ice cream-like characteristic, several food additives are added to ice cream. The formulation of the ice cream and choosing the proper materials are the key factor to produce desirable ice cream. This manuscript summarized the development of ice cream products from different ingredients of milk substitutes that influence the overrun, viscosity, and melting resistance of the products.
\end{abstract}

\section{Introduction}

Ice cream is a cold food product that is semi-solid, which is made using the unfrozen blend of ingredients such as milk, fat, sugar, and with or without other additives. It stands for one of the most eaten dairy products and has attained importance in dairy industries [1].According to Indonesia National Standard [2], the ice cream content must fulfil the predetermined requirements such as minimum fat content of $5 \%$, a minimum sugar content of $8 \%$, a minimum total solid amount of $3.4 \%$, and a minimum protein content of $2.7 \%$. Besides, the components of ice cream can be combined in varying formula and contribute to the rheological characteristics of ice cream. According to [3], ice cream generally contains seven categories of ingredients: fat (dairy or non-dairy), milk solids-not-fat (the principal source of protein), sweeteners, stabilizers, emulsifiers, water, and flavors. Depends on the formulation, ice cream can be divided into several categories (Table 1).

Fat content plays a significant role in the creamy and smooth texture. During storage, the ice and lactose crystals grow and involves the appearance of large crystals and fusion of crystals, and the vanishing of small crystals [4]. The large crystals development on ice cream make the coarse texture and become the indicator of the shelf life of the product. The fat globule prevents the growth of ice crystal during storage and preventing the coarseness of texture $[1,5]$ Fat helps increasing the thickness, stability of the dough, and slow down the rate of resistance [6,7]. Besides, fat content influences the flavor perception of the ice cream, as high fat content helps to prolong the flavor release until reach the maximum intensity [8]. 
Sugar is considered as an economically important ingredient in ice cream. It is not only for giving sweet taste but also influences the total solid content of the product [9]. The addition of sugar also increases viscosity, improves body and texture, and decreases the freezing point that reduces the risk of large ice crystals formation [10]. The combination of corn syrup solid made from hydrolysis of corn starch and sucrose are the most typical choice of sweeteners mixtures [3].

Table 1. Ice cream composition (\% wt.) by formulation category [3]

\begin{tabular}{|c|c|c|c|c|c|}
\hline \multirow[b]{2}{*}{ Group } & \multicolumn{3}{|c|}{ Milk } & \multirow[b]{2}{*}{$\begin{array}{c}\text { Stabilizers \& } \\
\text { Emulsifiers }\end{array}$} & \multirow[b]{2}{*}{$\begin{array}{r}\text { Total } \\
\text { Solids }\end{array}$} \\
\hline & Milk Fat & $\begin{array}{c}\text { Solid } \\
\text { Non-Fat }\end{array}$ & Sweeteners & & \\
\hline Nonfat ice cream & $<0.5$ & $12-14$ & $18-22$ & 1.0 & $28-32$ \\
\hline Low fat ice cream & $2-5$ & $12-14$ & $18-21$ & 0.8 & $28-32$ \\
\hline Light ice cream & $5-7$ & $11-12$ & $18-20$ & 0.5 & $30-35$ \\
\hline $\begin{array}{l}\text { Reduced-fat ice } \\
\text { cream }\end{array}$ & $7-9$ & $10-12$ & $18-19$ & 0.4 & $32-36$ \\
\hline Economy ice cream & 10 & $10-11$ & $15-17$ & 0.4 & $35-36$ \\
\hline Standard ice cream & $10-12$ & $9-10$ & $14-17$ & $0.2-0.4$ & $36-38$ \\
\hline Premium ice cream & $12-14$ & $8-10$ & $13-16$ & $0.2-0.4$ & $38-40$ \\
\hline $\begin{array}{l}\text { Super premium ice } \\
\text { cream }\end{array}$ & $14-18$ & $5-8$ & $14-17$ & $0-0.2$ & $40-42$ \\
\hline
\end{tabular}

The stabilizer plays a role in the homogenization process between ingredients and as an emulsifier for the ingredients found in ice cream dough. It also helps emulsify the water and fat to stick together and reduce ice and lactose crystal growth during storage. The stabilizer can also give the ice cream a smoother texture and help slow-melting down [11]. The good stabilizers must not give any unwanted flavor, not react with ice cream flavor, provide good meltdown properties and desirable texture [3,11]. The stabilizers sometimes are joined with emulsifiers in mixtures, with each of them has their own mechanism of function. Both of them influence the whipping quality of the ice cream, facilitates molding, giving the product a smooth texture, good stand-up, and resistance properties [11]. The use of these ingredients in ice cream processing could influence the physical characteristic of the product in terms of overrun, viscosity, and melting resistance. These properties are considered essential for manufacturing high-quality ice cream [12]. The innovation of the ice cream product using non-dairy based is increasing in recent years. The consumers with specific needs, such as lactose intolerants and vegans, have been searching for new alternatives for lactose-free products [13]. Moreover, many consumers have increased awareness and demand for consuming nutritious food with functional properties for maintaining well-being [13]. It has become a challenge and attracts the food industry in developing new ice cream products containing ingredients for specific purposes [14]. In this manuscript, we summarized the development of ice cream products from different milk substitutes that influence the overrun, viscosity, and melting resistance of the products.

\section{Milk substitutes in ice cream manufacturing}

The production of high-quality ice cream products is influenced by selecting ingredients with excellent quality, the formulation that balances each component's proper function, and suitable processing methods [11]. However, the choice of high-quality ingredients is an essential factor in successful ice cream manufacturing. The clean, fresh, creamy flavor desired in ice cream can be achieved only by using ingredients that have been carefully produced and handled and are themselves of excellent flavor quality [11]. The consumption of ice cream using dairy ingredients as the primary materials is due to tradition, availability, and nutritional values.

The rising prevalence of lactose intolerance and milk-related allergies, also the increasing popularity of the vegan lifestyle, contribute to the development of non-dairy ice cream [13]. Non-dairy products or milk-substitutes, the liquids obtained from plant-based, are the popular materials used in 
non-dairy ice cream manufacturing. However, due to the difference in chemical fat content, it does not exhibit the same physical properties as dairy ice cream. These components influence the physical characteristic (viscosity, overrun, and melting time) of the final products.

Table 2 showed the ice cream product's summary with different non-dairy substitutes that affect the viscosity, melting time, and overrun. The use of non-dairy ingredients to substitute cow's milk, such as fruits, legumes, tubers, and cereals, has been regarded and widely utilized as alternative materials for ice cream production. Besides, the uses of these ingredients could give some additional healthy values due to the nutrition and bioactive compounds [15]. Due to the differences in the total solid content, the right ingredients mixed and balanced are essential to produce a satisfying composition.

The addition of fruit and other carbohydrate-based materials influence the total solid content. The addition of fruit with low acidity could decrease the total solid and overrun of the ice cream due to the organic acid that disturbs the air bubble stability [15]. Moreover, the fiber content in the fruit, such as pectin, could increase the viscosity and give a good melting resistance to the product [15]. The mechanism of action of fiber is contributed by the retention of water in the serum concentration of ice cream [15]. The addition of hydrocolloids such as carrageenan, guar gum, and CMC could improve the stability of ice cream through hydration and swelling [11,15].

The uses of legumes and tubers in ice cream making are quite common for non-dairy ice cream production, for example, the use of soybean in ice cream making. Soy milk has been used as milk substitutes due to their functionalities, such as water-holding capacity, water-binding, emulsifying ability, and stability [16]. Soy milk contains a high total solid that influence the increase in viscosity and melting rate. Another milk substitute from Table 2 also showed the tendency that increases the concentration of milk substitutes will increase viscosity, increase the melting rate, and decrease the overrun content.

Table 2. Composition of ice cream ingredients and physical parameters(overrun, viscosity, melting time)

\begin{tabular}{|c|c|c|c|c|}
\hline \multirow[b]{2}{*}{ Ingredients } & \multicolumn{3}{|c|}{ Parameters } & \multirow[b]{2}{*}{ References } \\
\hline & $\begin{array}{c}\text { Overrun } \\
(\%)\end{array}$ & $\begin{array}{c}\text { Viscosity } \\
\text { (cP) }\end{array}$ & $\begin{array}{c}\text { Melting Time } \\
\text { (minutes) }\end{array}$ & \\
\hline Milk (Fat 10\%) & 34.5 & 1573 & - & \multirow{3}{*}{ [1] } \\
\hline Milk (Fat 3-6\%) + WPI & 25.3 & $15253-22566$ & - & \\
\hline Milk (Fat 3-6\%) + Inulin & 39.2 & 952-988 & - & \\
\hline Milk & 38.77 & 20000 & 20.79 & \multirow{7}{*}{ [15] } \\
\hline Milk + PPP $(0.25-0.5 \%)$ & $33.65-30.12$ & $26000-37600$ & $17.49-17.43$ & \\
\hline Milk + DFS (2.5-5.0\%) & $28.54-27.52$ & $2400-77600$ & $21.18-17.98$ & \\
\hline Milk + PPP $(0.25 \%)+$ DFS $(2.5 \%)$ & 31.30 & 8800 & 19.96 & \\
\hline Milk + PPP $(0.25 \%)+$ DFS $(5 \%)$ & 23.71 & 18400 & 21.44 & \\
\hline Milk + PPP $(0.5 \%)+$ DFS $(2.5 \%)$ & 16.63 & 28000 & 17.42 & \\
\hline Milk + PPP $(0.25 \%)+$ DFS $(5 \%)$ & 15.20 & 78400 & 17.05 & \\
\hline Milk (Fat 12-16\%) + CMC & $71.1-76.0$ & - & - & \multirow{2}{*}{ [17] } \\
\hline Milk (Fat 12-16\%) + Gelatin & $72.6-81.15$ & - & - & \\
\hline Milk (Fat 12\%) & - & - & 10.67 & \multirow{5}{*}{ [18] } \\
\hline Milk (Fat 10\%) + Corn Oil (2\%) & - & - & 8.98 & \\
\hline Milk (Fat $10 \%)+$ Soybean Oil (2\%) & - & - & 9.31 & \\
\hline Milk (Fat 10\%) + Coconut Oil (2\%) & - & - & 9.77 & \\
\hline Milk (Fat 10\%) + Palm Oil (2\%) & - & - & 10.19 & \\
\hline Milk + Sweet Potato Pulp (12.5\%) & 99.73 & - & 35.66 & \multirow{2}{*}{ [19] } \\
\hline Soymilk $(25-100 \%)+$ Sweet Potato & $90.76-73.64$ & - & $28.13-20.53$ & \\
\hline
\end{tabular}




\begin{tabular}{|c|c|c|c|c|}
\hline \multicolumn{4}{|l|}{ Pulp $(12.5 \%)$} & \multirow[b]{3}{*}[20]{} \\
\hline Milk (100\%) & 25.67 & 1176 & 37.45 & \\
\hline $\begin{array}{l}\text { Milk }(100 \%)+\text { Sago Flour } \\
(2-6 \%)\end{array}$ & $25.14-20.14$ & $1750-3348$ & $39.13-48.28$ & \\
\hline $\begin{array}{l}\text { Black-eyed pea + Carrageenan } \\
(0.1-0.5)+\text { Whipping Cream }(10- \\
30 \%)\end{array}$ & $29.51-52.39$ & - & $10-15$ & [21] \\
\hline Soy Milk (100\%) & 74.67 & - & 16.46 & \multirow[b]{2}{*}{ [22] } \\
\hline $\begin{array}{l}\text { Soy Milk }(90-60 \%)+\text { Beet Extract } \\
(10-40 \%)\end{array}$ & $70.33-45.00$ & - & $18.43-24.38$ & \\
\hline $\begin{array}{l}\text { Purple Yam + Skim Milk }(8-12 \%) \\
+ \text { Fish Gelatin }(0.1-0.5 \%)\end{array}$ & $46.97-56.04$ & - & $34.93-43.99$ & [23] \\
\hline Milk & 74.80 & - & 18.17 & \multirow{2}{*}{ [24] } \\
\hline Milk + Red Rice Bran (15-60\%) & $72.85-59.51$ & - & $17.79-8.03$ & \\
\hline Soymilk + Seaweed $(0.3-0.4 \%)$ & $23.84-19.76$ & $6200-7500$ & $7.64-8.76$ & [25] \\
\hline Milk $(100 \%)$ & - & 289 & 35.88 & \multirow{5}{*}[26]{} \\
\hline Coconut Milk (100\%) & - & 363 & 27.00 & \\
\hline Soy Milk (100\%) & - & 1120 & 16.27 & \\
\hline $\begin{array}{l}\text { Milk }(25-75 \%)+\text { Soy Milk }(75- \\
25 \%)\end{array}$ & - & $818-398$ & $22.25-33.36$ & \\
\hline $\begin{array}{l}\text { Soy Milk }(75-25 \%)+\text { Coconut } \\
\text { Milk }(25-75 \%)\end{array}$ & - & $982-603$ & $18.11-26.50$ & \\
\hline Soy Milk & 39.42 & 1780 & - & \multirow{2}{*}{ [27] } \\
\hline Soy Milk + Guar Gum (0.3-0.6\%) & $46.89-57.27$ & $3273-4400$ & - & \\
\hline $\begin{array}{l}\text { Soy Milk }(90-50 \%)+ \\
\text { GingerExtract }(10-5-\%)\end{array}$ & $34.18-23.07$ & - & $28.20-13.60$ & [28] \\
\hline $\begin{array}{l}\text { Red Rice Milk + Full Cream (8- } \\
13 \%)\end{array}$ & $16.58-22.77$ & - & $21.05-17.51$ & [29] \\
\hline
\end{tabular}

\section{Overrun, viscosity, and melting rate relationship in ice cream}

The frozen product that consists of a dispersion of air cells in a liquid matrix is called ice cream. The major structural components of ice cream are ice crystals, fat globules, and air cells. They are distributed on the unfrozen liquid solution of the ice cream. In coalescent fat globules, the fat functions to cover and stabilize air cells [29]. The ice cream structure determines the melting rate of the product. When ice cream melts, the heat from the warm air surrounding the product will be transferred into the ice cream to melt the ice crystals. The melting will start from the outer part of the ice cream. The water from melting ice diffuses into the viscous unfrozen phase. Then, it flows through the structural elements [29].

There is an excellent association between melting rate and overrun. Warren and Hartel [30] stated that overrun contributes to the slower melting rate due to its insulator effect. It prevents the penetration of heat to ice cream during the meltdown process. Table 2 showed that the higher the overrun value, the slower the ice cream's melting rate and had an excellent melting resistance [30]. The production of ice cream using milk substitutes has different total solids and fat properties compared to the dairy ice cream. These differences could affect the fat destabilization that coat and support the air cells and also chains of fat globules that build a fat network in the ice cream [31]. As observed in [15], the uses of milk substitutes such as pomegranate peel could affect the air bubble stability.

Viscosity becomes an essential characteristic of ice cream as it determines the desirable texture of the final product. It also influences the melting resistance and overrun value of ice cream [29]. Table 2 
showed that the increased viscosity would decrease the overrun value of the ice cream. The low viscosity of the product could be caused by the high water content of the ingredients. On the contrary, the more viscous product could decrease the overrun, where the incorporation of the air cell was hindered due to the hydration of the ingredients [32]. Viscosity could also affect the melting rate of ice cream. When the serum phase of ice cream is more viscous, the drainage or melting process is slow due to the slower mobility of air cells and fat clusters, thus reducing the melting rate (time for melting is longer) [29].

Stabilizers (also known as holders and binders) were characterized by the long-chain polysaccharides that can bind water, protein, and fat. The addition of a stabilizer to the ice matrix could increase the viscosity, leading to lower overrun but has a good melting resistance [34,35]. It also prevents the separation of ice cream mixtures and gives a smooth texture of ice cream [36]. The smoothness and melting resistance of the ice cream have a linear relationship to the viscosity increase. The increasing viscosity contributes to the limitation of ice crystals growth during the recrystallization of the ice cream. This limitation is caused by the less entrapment of air and makes the air sized smaller [37].

The use of non-dairy milk as ice cream ingredients could affect the composition of the desirable ice cream. The ingredients with enough fat content could keep the water content within a reasonable limit to prevent the hard texture and icy product [11]. The differences in composition greatly influence the physical characteristic of the final product. The total solid of the products must be maintained within the required limit to obtain regular ice cream properties. Therefore, the formulation of the product becomes the critical point to the success of the development non-dairy ice cream.

\section{Conclusion}

The development of ice cream from milk substitutes has increased in recent years due to the health concerns of consuming dairy ice cream. Generally, the ice cream is usually comprised of a mixture of ingredients such as milk, fats (dairy or non-dairy), with or without food additives (sweeteners, stabilizers, emulsifiers). The use of non-dairy ingredients such as fruits, legumes, and nuts have been regarded as the great ingredients for the production of ice cream. These components can be combined in various formulations, with or without food additives such as emulsifier and stabilizer, to obtain the desirable and acceptable qualities. The formulation of ice cream from various ingredients could affect the product's physical properties in terms of overrun, viscosity, and melting time. Therefore, it should be noted that the formulation and the choice of ingredients are the key factors of the success of ice cream production. Besides, several considerations must be counted into accounts, such as law regulations, product quality, the availability of raw materials, unit operations for production, market demands, product competitor, and expenditure.

\section{Acknowledgement}

We want to thank Bina Nusantara University Research and Technology Transfer Office (RTTO) for providing financial assistantship for the conference and publication.

\section{References}

[1] Akalın A S, Karagözlü C and Ünal G 2008 Rheological properties of reduced-fat and low-fat ice cream containing whey protein isolate and inulin Eur. Food Res. Technol. 227 889-95

[2] Badan Standarisasi Nasional Indonesia 2013 Standarmutu es krim dan batasmaksimumpenambahanbahantambahanpengemulsi dan penstabil. DepartementPerdagangan dan Perindustrian $120-24$.

[3] Goff H D and Wartel R H 2013 Ice Cream Seventh Edition (New York: Springer)

[4] Flores A A and Goff H D 1999 Recrystallization in ice cream after constant and cycling temperature storage conditions as affected by stabilizers J. Dairy Sci. 82 1408-15 
[5] Javidi F, Razavi S M A, Behrouzian F and Alghooneh A 2016 The influence of basil seed gum, guar gum and their blend on the rheological, physical and sensory properties of low fat ice cream Food Hydrocolloids 52 625-33

[6] Guzeler N, Kacar A and Say D 2011 Effect of milk powder, maltodextrin and ploydextrose use on physical and sensory properties of low calorie ice cream during storage. Academic Food $96-12$

[7] Wardana AS 2012 TeknologiPengolahan Susu(Surakarta: Universitas SlametRiyadi)

[8] Frøst M B, Heymann H, Bredie W L P, Dijksterhuis G B and Martens M 2005 Sensory measurement of dynamic flavour intensity in ice cream with different fat levels and flavouringsFood Qual. Prefer.16 305-14

[9] Silva Junior E da and Lannes S C da S 2011 Effect of different sweetener blends and fat types on ice cream properties Food Sci. Technol.31 217-20

[10] Darma G, Puspita D and Noerhartat E 2013 Pembuatan es krimjagungmaniskajianjeniszatpenstabil, konsentrasinon dairy cream sertaaspekkelayakanfinansial. J PenelitianTeknologiIndustriPertanian1 68

[11] Arbuckle W S 2013 Ice CreamFifth Edition(USA: The Avi Publisher Co.)

[12] Sofjan R P and Hartel R W 2004 Effects of overrun on structural and physical characteristics of ice cream Int. Dairy J.14 255-62

[13] Medeiros A C de, Filho E R T and Bolini H M A 2019 Impact of natural and artificial sweeteners compounds in the sensory profile and preference drivers applied to traditional, lactose-free, and vegan frozen desserts of chocolate flavor J. Food Sci.84 2973-82

[14] F A, Baba A S and Shori A B 2016 Effects of the replacement of cow milk with vegetable milk on probiotics and nutritional profile of fermented ice cream Lebensm.Wiss. Technol.70 26170

[15] Ismail H A, Hameed A M, Refaey M M, Sayqal A and Aly A A 2020 Rheological, physiochemical and organoleptic characteristics of ice cream enriched with Doum syrup and pomegranate peel Arab. J. Chem.13 7346-56

[16] Savio J, Preci D, Castelle M, Manzolli A, Fernandes I A, Junges A, Colet R, Carrão-Panizzi M, Abirached C, Steffens J and Valduga E 2018 Development and structural behaviour of soybean gelato Food Technol.Biotechnol.56 516-23

[17] Hartatie E S 2013 Kajian formulasi (bahanbaku, bahanpemantap) dan metodepembuatanterhadapkualitas es krimJ. Gamma7 20-26

[18] Dhani A U 2018 Pengaruhsubtitusi lemak susu denganberbagaiminyaknabatiterhadap total bahanpadat , tekstur dan waktupelelehanSeratAcitya6 44-49

[19] Pamungkasari D 2008 Kajian penggunaan susu kedelaisebagaisubstitusi susu sapiterhadapsifat es krim ubi jalar (Ipomoea batatas) (Semarang: Universitas SebelasMaret) pp 1-64

[20] Wijayanti I A, Purwadi P and Thohari I 2017 Pengaruhpenambahantepungsagu pada yoghurt terhadapviskositas, overrun, kecepatanmeleleh dan total padatan es krim yoghurt JITEK10 $28-35$

[21] Praptiningsih Y, Tamtarini and Rahma A 2013 Karakteristik es krim susu kacangtunggak (Vigna unguiculata L.) denganvariasijumlahkaragenan dan whipping creamJ. Agrotek.7 $151-156$

[22] Liana L, Ayu D F and Rahmayuni R 2017 Pemanfaatan susu kedelai dan ekstrakumbi bit dalampembuatan es krimJOMBidangPertanian4 1-10

[23] Velly H 2018 Pengaruhkonsentrasigelatintulang ikan patin (Pangasius sp.) dan konsentrasi susu skim terhadapkarakteristik es krim ubi jalarungu (Ipomoea batatas L.) Pasundan Food Technol. J. (PFTJ)5 122-32

[24] Lisdyareni F N M, Widarta I W R and Sugitha I $M \quad 2016$ Pengaruhpenambahanbekatulberasmerahterhadapsifatfisik, kimia, dan sensoris es krimJ.IlmuTeknol. Pangan (ITEPA)5 64-73 
[25] Violisa A, Nyoto A and Nurjanah N 2013 Penggunaanrumputlautsebagai stabilizer es krim susu sari kedelaiJ Teknol. KejuruanPengajaran.35 103-14

[26] Aboulfazli F, Baba A S and Misran M 2014 Effect of vegetable milks on the physical and rheological properties of ice cream Food Sci. Technol. Res.20 987-96

[27] Ahsan S, Zahoor T, Hussain M, Khalid N, Khaliq A and Umar M 2015 Preparation and quality characterization of soy milk based non-dairy ice cream Int. J. Food Allied Sci.1 25-31

[28] Widiantoko R K and Yunianta Y 2013 Pembuatan es krimtempe - jahe (kajianproporsibahan dan penstabilterhadapsifatfisik, kimia dan organoleptik) J. PanganAgroind.2 54-66

[29] Muse M R and Hartel R W 2004 Ice cream structural elements that affect melting rate and hardness J. Dairy Sci. 87 1-10

[30] Warren M M and Hartel R W 2018 Effects of emulsifier, overrun and dasher speed on ice cream microstructure and melting properties J. Food Sci. 83 639-47

[31] Wu B, Freire D O and Hartel R W 2019 The effect of overrun, fat destabilization, and ice cream mix viscosity on entire meltdown behaviorJ. Food Sci. 84 2562-71

[32] Marshall R T, Goff H D and Hartel R W 2003 Ice Cream Ingredients Ice Cream ed R T Marshall, H D Goff and R W Hartel (Boston, MA: Springer US) pp 55-87

[33] Milliatti M C, Lannes S C da S, Milliatti M C and Lannes S C da S 2018 Impact of stabilizers on the rheological properties of ice creams Food Sci. Technol.38 733-9

[34] Kurultay Ş, Öksüz Ö and Gökçebağ Ö 2010 The influence of different total solid, stabilizer and overrun levels in industrial ice cream production using coconut oil J. Food Proces. Preserv. 34 346-54

[35] Bolliger S, Goff H D and Tharp B W 2000 Correlation between colloidal properties of ice cream mix and ice cream Int. Dairy J.10 303-9

[36] Syed Q A, Anwar S, Shukat R and Zahoor T 2018 Effects of different ingredients on texture of ice cream J NutrHealt Food Eng8 422-35

[37] Soukoulis C, Lebesi D and Tzia C 2009 Enrichment of ice cream with dietary fibre: Effects on rheological properties, ice crystallisation and glass transition phenomena Food Chem.115 $665-71$ 